\title{
Transitional cell tumours of the lacrimal drainage apparatus*
}

\author{
Ahmed Z. Eweiss',2, Valerie J. Lund', Amrita Jay³, Geoffrey Rose ${ }^{4}$ \\ Rhinology 51: 349-354, 2013 \\ DOI:10.4193/Rhino13.016 \\ 'Royal National Throat Nose and Ear Hospital, London, United Kingdom \\ ${ }^{2}$ Otolaryngology Department, Faculty of Medicine, University of Alexandria, Egypt \\ *Received for publication: \\ ${ }^{3}$ Histopathology Department, University College Hospital, London, United Kingdom \\ February 15, 2013 \\ ${ }^{4}$ Moorfields Eye Hospital, London, United Kingdom \\ Accepted: May 28, 2013
}

\section{Summary}

Background: Tumours of the lacrimal drainage apparatus (LDA) are very rare, but can be life-threatening. Seventy percent of lacrimal sac tumours are of epithelial origin, and transitional cell tumours represent an interesting sub-group of these epithelial tumours.

Methods: A retrospective review of cases of LDA transitional cell tumours co-managed at the Royal National Throat Nose and Ear Hospital and Moorfields Eye Hospital, London.

Results: Twenty cases of transitional cell tumours of the LDA were identified, comprising 10 transitional cell papillomas (TCPs) and 10 transitional cell carcinomas (TCCs). All cases were resected through a modified lateral rhinotomy approach. Limited resection of orbital fat with preservation of orbital functions was required for 2 cases of TCC. Fractionated external beam radiotherapy was administered in 7 cases of TCC. The mean follow up was 80 months (range 11 months-16 years). Recurrences were detected in 4 cases, which were managed by further surgery. Two cases have been lost to follow-up, but the 18 other patients are currently alive and disease free.

Conclusion: A favourable outcome can be achieved with transitional cell tumours of the LDA when an optimum management plan is followed.

Key words: transitional cell papilloma, transitional cell carcinoma, lacrimal drainage apparatus, lacrimal sac, lateral rhinotomy

\section{Introduction}

Tumours of the lacrimal drainage apparatus (LDA) are very rare, but can be life threatening ${ }^{(1)}$. A recent meta-analysis of the literature about tumours arising primarily in the lacrimal sac showed $72 \%$ of these tumours to be malignant, and $70 \%$ to be of epithelial origin ${ }^{(2)}$. The epithelial lining of the lacrimal drainage apparatus is heterogenous, ranging from non-keratinised stratified squamous epithelium in the canaliculi, to a ciliated respiratory epithelium in the lacrimal duct and nose. The lacrimal sac is lined by stratified columnar epithelium with foci of ciliated respiratory epithelium. This heterogeneity accounts for the variety of epithelial tumours that can arise from the lacrimal drainage apparatus ${ }^{(3,4)}$. Squamous papilloma was the commonest benign epithelial tumour in a large group of lacrimal sac tumours, followed by transitional cell papilloma, while the commonest malignancy was squamous cell carcinoma, followed by carcinomas arising within papillomas and then transitional cell carcinoma ${ }^{(5)}$.

Transitional cell tumours of the LDA represent an interesting sub-group, forming about $16 \%$ of lacrimal sac tumours in one series ${ }^{(5)}$. Transitional cell papillomas (TCPs) are benign tumours composed of stratified columnar epithelium with scattered goblet cells. Transitional cell carcinomas (TCCs) histo-pathologically resemble transitional carcinomas of the urinary bladder ${ }^{(2,6)}$, 
with the tumour cells arranged in broad sheets with smooth borders and surrounded by basement membrane-like material. Although the cells are mainly non-keratinised, keratinisation of individual cells may be identified ${ }^{(7)}$. Transitional cell carcinoma has many synonyms, including "non keratinising carcinoma", "intermediate cell carcinoma" and "Schneiderian carcinoma" (8). There has been some evidence that Human Papilloma Virus (HPV) types 6, 11 and 16 may be involved in the aetiology of these tumours ${ }^{(9)}$.

In the current study we report our experience with management of transitional cell tumours of the LDA.

\section{Materials and methods}

A retrospective review of all cases of transitional cell tumours arising from the LDA managed between 1970 and 2011 was undertaken. The case notes and, where available, the histopathology specimens were reviewed to confirm the diagnosis. All cases proven to be other than transitional cell tumours, or originating outside the LDA, were excluded.

\section{Results}

By case notes reviews for 32 patients with tumours arising from the LDA, 21 were identified with transitional cell tumours, including 11 patients with TCPs and 10 with TCCs.

Histopathology specimens were reviewed for 17 patients, of which, 10 were benign, and 7 were malignant. The 10 benign cases included 9 TCPs and 1 case found to be a squamo-proliferative benign lesion. The latter case was therefore excluded. All 7 malignant cases were confirmed to be TCCs. Tissue review was unavailable for 4 patients, but these patients had unequivocal contemporaneous diagnoses rendered by the then Professors of ENT Histopathology and Ophthalmic Histopathology at the Royal National Throat Nose and Ear Hospital and Moorfields Eye Hospital- being one patient with TCP and 3 with TCCs; the final series therefore included 10 TCPs and 10 TCCs.

Both TCP and TCC showed a female preponderance (6/10 TCP

Table 1. Demographics of 20 patients with transitional cell tumours of lacrimal drainage apparatus.

\begin{tabular}{|c|c|c|c|c|}
\hline & $\begin{array}{c}\text { Number of } \\
\text { patients }\end{array}$ & $\begin{array}{c}\text { Age in } \\
\text { years } \\
\text { (mean } \pm \\
\text { standard } \\
\text { deviation) }\end{array}$ & male & female \\
\hline $\begin{array}{l}\text { Transitional } \\
\text { cell papil- } \\
\text { loma (TCP) }\end{array}$ & 10 & $\begin{array}{c}28-82 \\
\text { mean } 48.64 \\
( \pm 15.92)\end{array}$ & 4 & 6 \\
\hline $\begin{array}{l}\text { Transitional } \\
\text { cell carci- } \\
\text { noma (TCC) }\end{array}$ & 10 & $\begin{array}{c}46-81 \\
\text { mean } 56.33 \\
( \pm 11.24)\end{array}$ & 3 & 7 \\
\hline
\end{tabular}

patients and 7/10 TCC) and patients with TCP presented for treatment at a slightly younger age (mean 48.6 years; range 2882) than those with TCC (mean 56.33 years; range $46-81$ years) (Table 1).

All patients presented with epiphora and a medial canthal mass was present in 3/10 TCP and 7/10 TCC patients; 2 patients ( 1 with TCC and 1 with TCP) had mild proptosis, and the latter patient also had a blood stained nasal discharge.

All patients presented initially to ophthalmologists with epiphora and, where a preoperative mass was not present, underwent a dacrocystogram to confirm the site of nasolacrimal obstruction. In these cases, the diagnosis was made after biopsy of abnormal tissues which were unexpectedly encountered during open dacryocystorhinostomy (DCR). One third (35\%) of patients had multiple lacrimal surgeries before the true and unsuspected diagnosis was established at the site of DCR (Figure 1). Once the diagnosis was established, imaging in the form of CT scans was arranged if not already undertaken. Patients who presented initially with an inner canthal swelling had a CT scan, that typically showed a soft-tissue mass in the lacrimal sac fossa, followed by biopsies undertaken by their treating ophthalmologists, prior to referral for definitive treatment (Figures 2, 3). After the tissue diagnosis, all patients were referred to the senior author (VJL) for oncologic resection of the lacrimal sac tumours.

All tumours were exposed through a modified lateral rhinotomy, thus allowing wide local excision of the entire naso-lacrimal system -- including the canaliculi, lacrimal sac and nasolacrimal duct, as well as the original DCR skin incision. In combination with the lateral rhinotomy approach, a rigid $4 \mathrm{~mm} 0^{\circ}$ Hopkins rod telescope was used to visualise the inferior part of the naso-

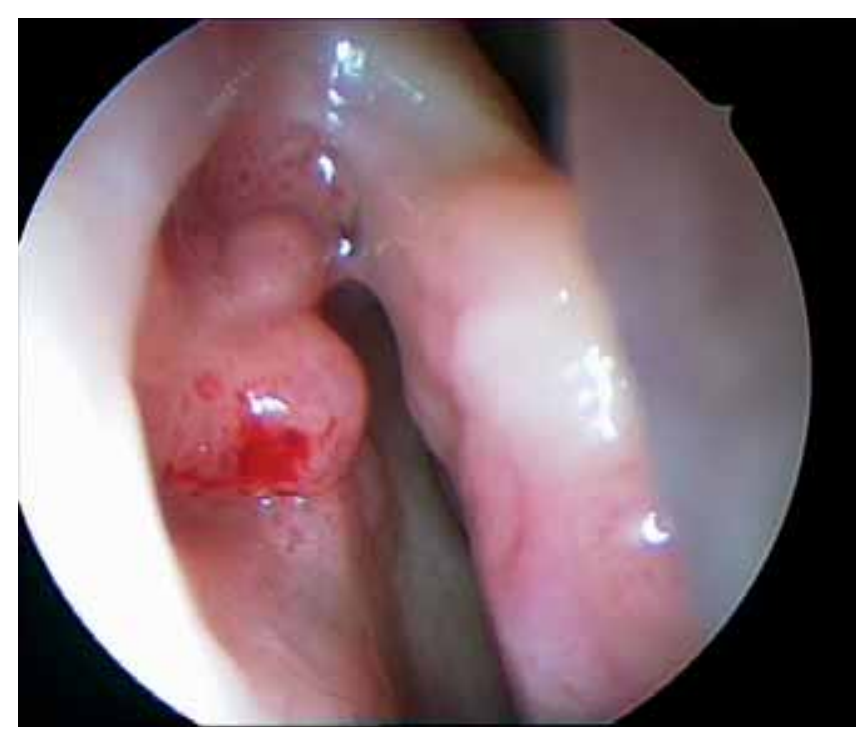

Figure 1. An endoscopic endonasal view showing a transitional cell papilloma arising from the right lacrimal sac after previous external dacryocystorhinostomy. 


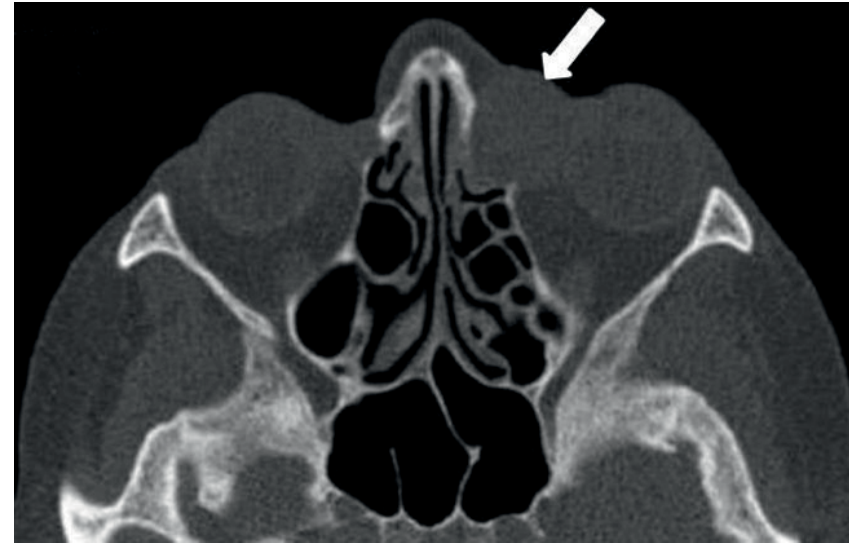

Figure 2. Axial CT showing a mass arising from the left lacrimal sac (arrow), with histology- proven transitional cell papilloma.

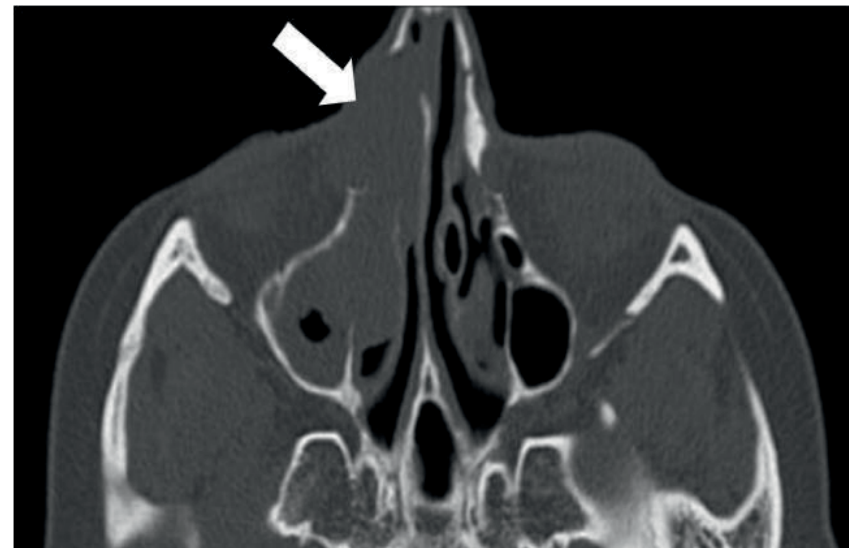

Figure 3. Axial CT showing a right lacrimal sac mass (arrow) causing erosion of the lacrimal bone and frontal process of the maxilla. Histology showed transitional cell carcinoma.

Table 2. Clinical results for 20 patients with transitional cell tumours of lacrimal drainage apparatus.

\begin{tabular}{|c|c|c|c|c|c|c|c|c|}
\hline & \multicolumn{4}{|c|}{ Clinical presentation } & \multicolumn{2}{|c|}{ Surgery } & \multicolumn{2}{|c|}{ Adjunctive therapy } \\
\hline & Epiphora & $\begin{array}{l}\text { Medial can- } \\
\text { thal swelling }\end{array}$ & Proptosis & $\begin{array}{l}\text { Bloody nasal } \\
\text { discharge }\end{array}$ & $\begin{array}{c}\text { Lateral } \\
\text { rhinotomy }\end{array}$ & $\begin{array}{l}\text { Localised } \\
\text { orbital } \\
\text { resection }\end{array}$ & Radiotherapy & $\begin{array}{c}\text { Orbital } \\
\text { Exenteration }\end{array}$ \\
\hline $\begin{array}{l}\text { Patients with } \\
\text { TCP (10) }\end{array}$ & 10 & 3 & 1 & 1 & 10 & 0 & 0 & 0 \\
\hline $\begin{array}{l}\text { Patients with } \\
\text { TCC (10) }\end{array}$ & 10 & 7 & 1 & 0 & 10 & 2 & 7 & 1 \\
\hline
\end{tabular}

lacrimal duct and to aid resection of the mucosa of the adjacent lateral nasal wall, the orbital periosteum, the anterior ethmoids and the anterior part of the middle turbinate. Two patients had resection of orbital fat, but with retention of good orbital functions.

Seven patients with TCC (70\%) received post-operative fractionated external beam radiotherapy, and 1/7 (16\%) subsequently required total maxillectomy and orbital exenteration to treat recurrent disease. This latter patient then developed a further recurrence and was lost to follow up at 48 months after initial diagnosis. (Table 2).

As expected, all patients developed epiphora, this being treated successfully with placement of Lester Jones canalicular bypass tubes. No other surgical complications were reported.

The follow up ranged from 11 months - 16 years with an average of 80 months.

Two patients with TCP developed multiple small recurrences that were treated with endonasal resections and KTP laser ablation; interestingly, one of these patients also had a vocal cord papilloma.

One patient with TCC developed a separate nodule of biopsy- proven squamous cell carcinoma on the ipsilateral lower eye lid at 3 months after the rhinotomy, and this was successfully treated with radiotherapy.

None of the patients with TCC died from the disease, although 1 disease-free patient was lost to follow up at 15 months after treatment (Table 3).

Table 3. Outcomes of treatment in 20 patients with transitional cell tumours of lacrimal drainage apparatus.

\begin{tabular}{|c|c|c|c|}
\hline & $\begin{array}{c}\text { Alive, tumour- } \\
\text { free }\end{array}$ & $\begin{array}{l}\text { Alive, tumour- } \\
\text { free after } \\
\text { treatment of } \\
\text { recurrence }\end{array}$ & $\begin{array}{l}\text { Alive, with } \\
\text { tumour recur- } \\
\text { rence }\end{array}$ \\
\hline $\begin{array}{l}\text { Patients with } \\
\text { TCP (10) }\end{array}$ & 10 & 2 & 0 \\
\hline $\begin{array}{l}\text { Patients with } \\
\text { TCC (10) }\end{array}$ & $9^{*}$ & 1 & $1^{\wedge}$ \\
\hline
\end{tabular}

* One patient was lost to follow up after 15 months.

^ Patient lost to follow up after 48 months. 


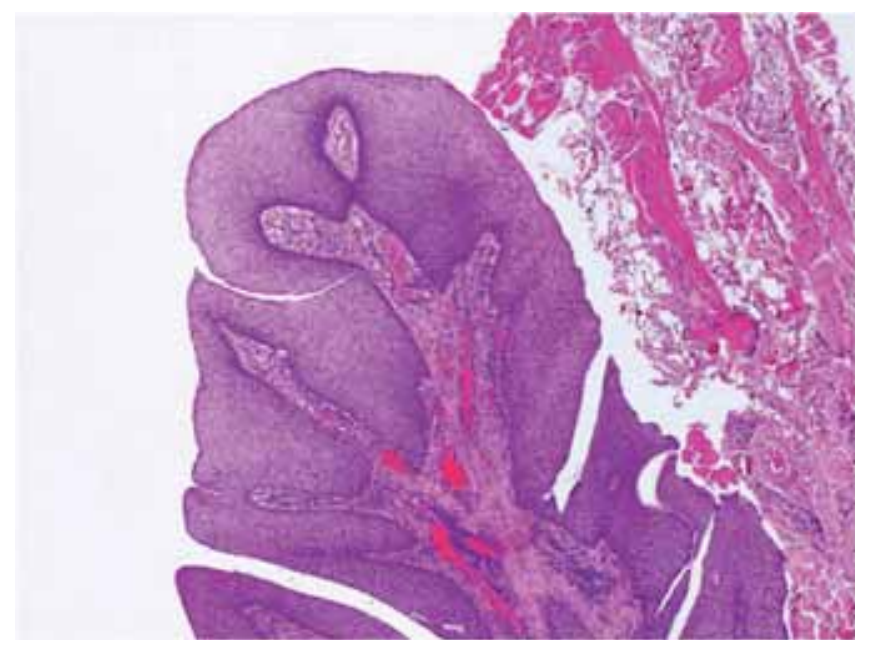

Figure 4. Transitional cell papilloma displaying exophytic growth (H\&E section, magnification $4 \times 10$ ).

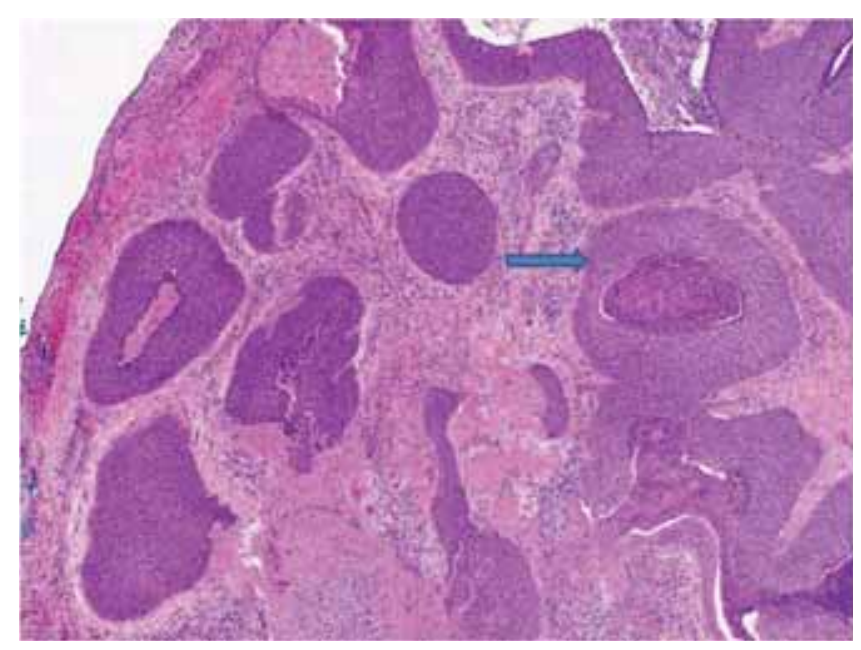

Figure 5. Transitional cell (non- keratinising) carcinoma featuring transitional cells and invasion in the form of interconnected and smoothedged epithelial down-growths (arrow) (H\&E section, magnification 10x10).

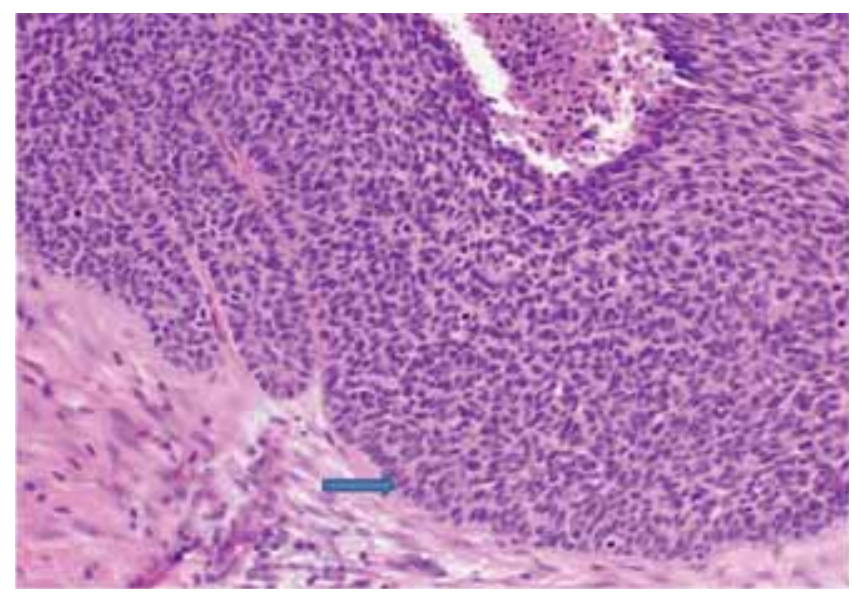

Figure 6. Transitional cell (non- keratinising) carcinoma featuring marked epithelial atypia, but with a "pushing" invasion front (arrow) (H\&E section, magnification $25 \times 10$ ).

\section{Histopathology}

Histopathology specimens were available for review in 17 patients, and one squamo-proliferative lesion was excluded from the series.

Among the 9 TCP cases, 4 were exophytic (Figure 4), 1 was endophytic and 4 had mixed exophytic and endophytic pattern of growth.

Low grade dysplasia was identified in 1 exophytic and 1 endophytic papillomas, and koilocyte - like cells (suggestive of HPV infection) were identified in 3 exophytic papillomas; dysplasia was absent in the latter 3 cases.

Among the 7 TCC cases, 6 were non keratinised, and 1 had minimal keratin formation. Transitional epithelium, although present by definition in all cases, was the predominant epithelium in 4 cases.

All cases of TCC showed a combination of exophytic and predominantly endophytic growth pattern.

Three cases of TCC showed stromal invasion in the form of infiltrative islands, and the other 4 cases displayed deep interconnected broad ribbons of epithelium with a pushing invasion front or detached cystic islands with smooth periphery (Figures $5,6)$.

Lymphovascular invasion was detected in 2 cases of TCC, but none showed perineural invasion or koilocytes.

\section{Discussion}

The literature about transitional cell tumours of the lacrimal drainage apparatus is very sparse and all previous reports have presented more diverse pathologies that only include very few transitional cell tumours. Ni et al. ${ }^{(10)}$ reported 82 cases of lacrimal sac tumours, with only 6 TCCs and no TCPs, and another series ${ }^{(5)}$ reported 13/115 TCPs and 5/115 TCCs. A report summarising the 63 year experience of a large cancer centre with malignancies of the lacrimal gland and LDA included only 1 case of TCC among 46 tumours ${ }^{(11)}$. The current report is, to the best of our knowledge, the first to report on transitional cell tumours of the LDA as a separate histo-pathological group and, as such, represents the largest series to date; all patients were under the care of a single surgeon (VJL).

Presentation of lacrimal sac tumours is typically in the sixth decade: Ryan and Font ${ }^{(6)}$ record a mean age of 55 in 27 patients with epithelial tumours, $\mathrm{Ni}{ }^{(10)}$ found the peak incidence among 82 patients to be 51-60 years, and Parmar and Rose ${ }^{(1)}$ had a median age of 59 years for patients with epithelial and nonepithelial tumours. Whilst Stefanyszyn ${ }^{(5)}$ reports a mean age of 52 years for 115 patients with different histopathologies, they noted that patients with papillomas were younger (mean age 44 years) as compared to those with carcinomas (mean 58 years). Interestingly, in their study, patients with TCP were younger than those with squamous papilloma and, similarly, patients with TCC were younger than those with other forms of carcinoma. In accordance with all other reports, our results show a mean age 
of 56 years for patients of TCC, marginally older than the 49 year average for patients with TCP. Gender predilection varies across reported series, this study showing a predominance (65\%) of females, but others showing a male predilection ${ }^{(5,10)}$, or female dominance ${ }^{(1)}$.

The commonest presenting symptom reported in the literature is generally epiphora (all of this series), followed by medial canthal swelling (a half of this series) ${ }^{(1,5,10,12)}$, but other presentations included proptosis, punctal bleeding and epistaxis or blood-stained nasal discharge ${ }^{(1,5,10,12)}$. Ni and colleagues ${ }^{(10)}$ recorded an unusually high incidence (28\%) of lymphatic spread, and uniquely report patients who first present with cervical lymphadenopathy; indeed, one patient presented with a submaxillary nodal metastasis 3 years prior to identification of a primary TCC of the lacrimal sac.

A tumour diagnosis was initially missed in $35 \%$ of our patients, a proportion similar to the $32 \%$ in another series ${ }^{(5)}$, and this finding opens the debate as to whether routine biopsies should be done during all lacrimal drainage surgery. However, a prospective study and literature review ${ }^{(13)}$ showed only 7/1294 (0.5\%) lacrimal sac biopsies to have unsuspected pathology, with only 1 malignancy; the authors of this study suggest that biopsy needs to be undertaken only where there is pre-operative or intraoperative suspicion of tissue abnormality. It also explains why CT scanning is not routinely performed in all cases of epiphora. Indeed even when a tumour is known to be present, neither CT nor MRI can determine with complete accuracy the degree of intraperiosteal spread and consequent fat resection and this decision must be made at the time of the surgical excision ${ }^{(14)}$. Lacrimal sac papillomas are predominantly exophytic ${ }^{(5)}$ and this accords with the current study identifying 4 exophytic, 1 endophytic (and 4 mixed) TCPs. Although HPV infection was not assessed in our cases, koilocytic changes, suggestive of HPV infection, were present in 3 exophytic TCPs. In a study involving epithelial lacrimal sac tumours, HPV DNA was identified in all 8 included cases of TCP and TCC, but was not identified in the 2 included cases of squamous cell carcinomas ${ }^{(9)}$.

Tumours of the LDA are usually resected primarily, with adjunctive radiotherapy or chemotherapy. Due to the rarity of these lesions, no international consensus exists regarding their management. The extent of surgery varies according to authors: Stefanyszyn ${ }^{(5)}$ treated most with DCR and local tumour resection, reserving more extensive surgery for invasive lesions, whereas $\mathrm{Ni}^{(10)}$ recommends dacryocystectomy for benign tumours and wider excision for malignant ones. Ni found that many recurrent lesions were attributable to tumour extension along the nasolacrimal duct and thus recommended initial resection of the sac and duct through a lateral rhinotomy approach, together with orbital exenteration for any malignancy extending into the orbit; the prognosis in this latter group was not, however, improved with exenteration.
Another group of authors recommended a lateral rhinotomy approach with en-bloc excision of the entire drainage apparatus and adjacent bone for malignant tumours, and external dacryocystectomy with endonasal resection of the nasolacrimal duct for benign tumours. Post-operative radiotherapy was given for malignancies with narrow or positive resection margins ${ }^{(12,15)}$. The prognosis varied greatly among different studies, although most are not restricted to transitional cell tumours alone: at one end of the spectrum was a series of sac malignancies ${ }^{(10)}$ with $28 \%$ lymphatic spread and $9 \%$ distant metastases at presentation, this group having a 38\% mortality, but 100\% tumour-related mortality amongst their patients with TCC, after a follow-up period ranging from 1- 20 years. On the other hand, among 12 patients with various malignancies treated by Valenzuela and colleagues ${ }^{(12)}, 9$ remained tumour-free at a mean followup of 30 months and only 2 patients died of the disease - both having mucosal malignant melanoma with its recognised poor prognosis.

Similar to Valenzuela ${ }^{(12)}$, we used a lateral rhinotomy approach for complete excision of the whole lacrimal drainage apparatus in all of our cases; local orbital resection was needed in 2 patients with TCC and 70\% of the TCC patients received post-operative radiotherapy. In contrast to some series ${ }^{(10)}$, we have not had any tumour-related deaths or metastases from TCC. Loco-regional recurrence was limited to 2 patients with TCC and 2 patients with TCP: of these 4 patients, 3 were treated successfully with second surgery, whereas the 4th patient, who required salvage maxillectomy and exenteration for recurrence following radiotherapy, was lost to follow-up after developing a second recurrence. These results support our surgical approach of a total dacryocystectomy, excision of adjacent orbital periosteum and sinonasal mucosa which avoided orbital exenteration in all but one of twenty patients.

\section{Conclusion}

We present the largest series to date of transitional cell tumours of the LDA managed principally by an ENT surgeon with an interest in sinonasal neoplasia. Our results show that with an optimum management plan, a favourable outcome can be achieved in this group of patients.

\section{Authorship contribution}

$A E$ : Collected the data for the study, reviewed the literature and prepared the manuscript.

VJL: Originated the idea of the study and reviewed and modified the manuscript.

AJ: Shared in collection of data.

GR: Shared in collection of data.

\section{Conflict of interest}

The authors do not have any conflicts of interest to declare. 


\section{References}

1. Parmar DN, Rose GE. Management of lacrimal sac tumours. Eye. 2003; 17: 599-606.

2. Heindl LM, Junemann AGM, Kruse FE, Holbach LM. Tumours of the lacrimal drainage system. Orbit. 2010; 29: 298-306.

3. Font RL. Eyelids and lacrimal drainage system. In: Spencer WH (ed). Ophthalmic Pathology, vol 4. Philadelphia: Saunders; 1996: 2412-2427.

4. Bansal S, Khan AL, Hsuan J. Lacrimal sac mucous secreting adenocarcinoma. Orbit. 2008; 27: 199-201.

5. Stefanyszyn MA, Hidayat AA, Pe'er JJ, Flanagan JC. Lacrimal sac tumors. Ophth Plastic Reconstructive Surg. 1994; 10: 16984

6. Ryan ST, Font RL. Primary epithelial neoplasms of the lacrimal sac. Am J Ophth. 1973; 76: 73-88.

7. Thompson LDR. Sinonasal carcinomas. Curr Diagnostic Path. 2006; 12: 40-53.

8. Gil Z, Orr-Urtreger A, Vaskoboinik N, Trejo-Leider L, Spektor S, Shomrat R. Cytogenic analysis of sinonasal carcinomas.
Otolaryngol Head Neck Surg. 2006; 134: 654-660.

9. Sjo NC, von Buchwald C, Cassonnet P, et al. Human papilloma virus: cause of epithelial lacrimal sac neoplasia? Acta Ophthalmol Scand. 2007: 85: 551-556.

10. Ni C, D'amico DJ, Fan CQ, Kuo PK. Tumours of the lacrimal sac: A clinicopathological analysis of 82 cases. Int Ophthalmol Clin. 1982; 22: 121-140.

11. Skinner HD, Garden AS, Rosenthal DI, et al. Outcomes of malignant tumours of the lacrimal apparatus: The University of Texas MD Anderson Cancer Center Experience. Cancer. 2011; 117: 2801-2810

12. Valenzuela AA, Selva D, McNab AA, Simon GB, Sullivan TJ. En Bloc excision in malignant tumours of the lacrimal drainage apparatus. Ophth Plastic Reconstructive Surg. 2006; 22: 356-360.

13. Merkonidis C, Brewis C, Yung M, Nussbaumer M. Is routine biopsy of the lacrimal sac wall indicated at dacryocystorhinostomy? A prospective study and literature review. Br J Ophthalmol. 2005; 89:
1589-1591.

14. Madani G, Beale TJ, Lund VJ. Imaging of sinonasal tumours. Seminars in Ultrasound CT \& MRI. 2009; 30: 25-38.

15. Sullivan $T J$, Valenzuela AA, Selva $D$, McNab AA. Combined external endonasal approach for complete excision of the lacrimal drainage apparatus. Ophth Plastic Reconstructive Surg. 2006; 22: 169-172.

Ahmed Z. Eweiss

Royal National Throat Nose and Ear Hospital

London

United Kingdom

Tel: +44-78-4982 5904

E-mail: azews@yahoo.com

\begin{tabular}{|c|c|}
\hline \multicolumn{2}{|l|}{ 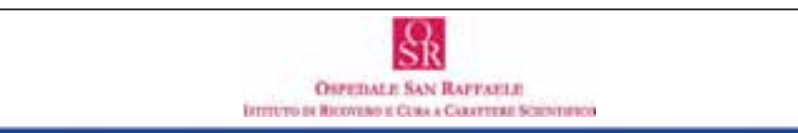 } \\
\hline \multicolumn{2}{|c|}{ SAVE THE DATE } \\
\hline \multicolumn{2}{|c|}{ RHINOPLASTY DISSECTION } \\
\hline \multicolumn{2}{|c|}{$\begin{array}{c}\text { Rhinoplasty International Course } \\
\text { March 11-12, } 2014\end{array}$} \\
\hline \multirow{2}{*}{\multicolumn{2}{|c|}{$\begin{array}{c}\text { Course Director } \\
\text { Prof. Mario Bussi, Ospedale San Raffaele, Milano } \\
\text { Tentative Faculty }\end{array}$}} \\
\hline & \\
\hline $\begin{array}{l}\text { M. Bussi (Italy) } \\
\text { L.P. Dombard (Belgium) } \\
\text { D. . Menger (The Netherlands) } \\
\text { P. Palma (Italy) }\end{array}$ & $\begin{array}{l}\text { V. Celik (Turkey) } \\
\text { H. Fodap (Egypt) } \\
\text { R. Mazzola (Italy) } \\
\text { S. Sciuto (Italy) }\end{array}$ \\
\hline \multicolumn{2}{|c|}{ REGISTRATION FEES } \\
\hline $\begin{array}{l}\text { March } 11 \text { - Theoretical course } \\
\text { March } 12 \text { - Handls-on dissection } \\
\text { (1 specimen shared among two I }\end{array}$ & $\begin{array}{l}\text { free of charge } \\
1.550,00 \text { VAT incl. } \\
\text { articipants) }\end{array}$ \\
\hline
\end{tabular}

